\title{
Factors Influencing Psychological Well-Being and Gender Among Private Financial Sector Employees in Malaysia
}

Mohamad Ibrani Shahrimin Adam Assim, Agilan Munusamy, Yasmin Yaccob, Nurul Hidayu Mat Jusoh, Salina Janis

To Link this Article: http://dx.doi.org/10.6007/IJARBSS/v11-i3/8835

DOI:10.6007/IJARBSS/v11-i3/8835

Received: 01 February 2021, Revised: 28 February 2021, Accepted: 06 March 2021

Published Online: 17 March 2021

In-Text Citation: (Assim et al., 2021)

To Cite this Article: Assim, M. I. S. A., Munusamy, A., Yaccob, Y., Jusoh, N. H. M., \& Janis, S. (2021). Factors Influencing Psychological Well-Being and Gender Among Private Financial Sector Employees in Malaysia. International Journal of Academic Research in Business and Social Sciences, 10(1), 331-351.

\section{Copyright: @ 2021 The Author(s)}

Published by Human Resource Management Academic Research Society (www.hrmars.com)

This article is published under the Creative Commons Attribution (CC BY 4.0) license. Anyone may reproduce, distribute, translate and create derivative works of this article (for both commercial and non-commercial purposes), subject to full attribution to the original publication and authors. The full terms of this license may be seen at: http://creativecommons.org/licences/by/4.0/legalcode

Vol. 11, No. 3, 2021, Pg. 331 - 351

Full Terms \& Conditions of access and use can be found at http://hrmars.com/index.php/pages/detail/publication-ethics 


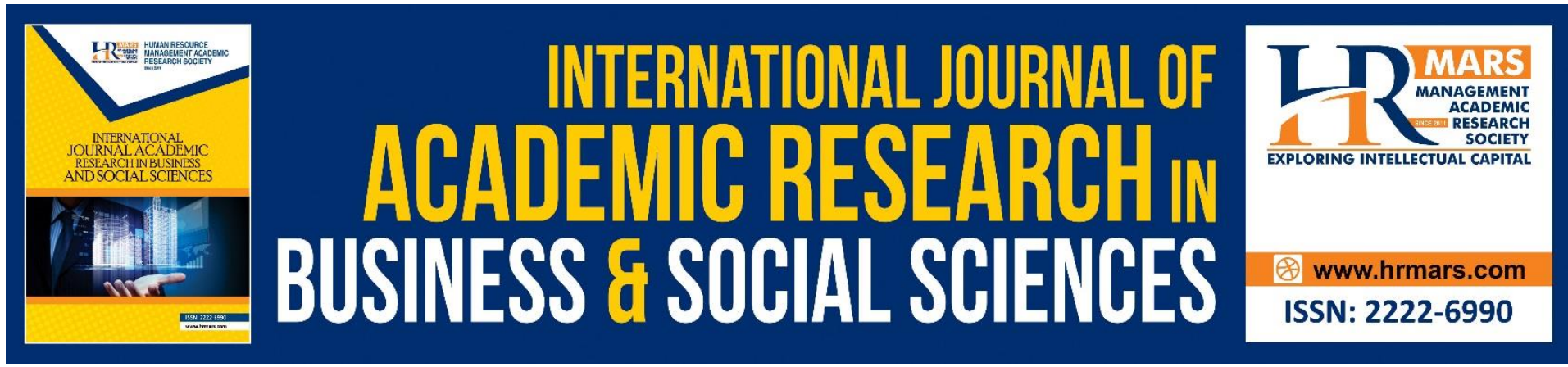

\title{
Factors Influencing Psychological Well-Being and Gender Among Private Financial Sector Employees in Malaysia
}

\author{
Mohamad Ibrani Shahrimin Adam Assim, Agilan Munusamy, \\ Yasmin Yaccob, Nurul Hidayu Mat Jusoh, Salina Janis \\ Faculty of Humanities, Management and Science, Universiti Putra Malaysia Bintulu Campus, \\ Sarawak, Malaysia \\ Email: ibrani@upm.edu.my
}

\begin{abstract}
This study examined the effect of coping strategy towards the relationship of psychology hardiness, well-being and gender among private financial institution sector employees in Malaysia. Correlations and differences pertaining to gender were also determined. A total of 141 employess from eleven private financial institutions in Malaysia participated in this study. A cross-sectional and correlational research design was employed. Psychology hardiness was measured using the dispositional Resilience [DRS-15 (v3.2)] scale, Coping strategy was measured using the Problem Oriented Brief Coping Experienced (BRIEF COPE) scale while Psychology well-being was measured using Well-being Manifestation Measure scale (WBMMS) scale. All hypotheses were tested and the results revealed that Coping Strategy had a significant role as a moderating variable. Further research is suggested to explore other possible moderating effects on psychology hardiness and well-being of banking employees in other domains of psychological attributes.
\end{abstract}

Keywords: Psychological Well Being, Private Sector Employees, Moderating Effects,

Psychology Hardiness, Banking Employees.

\section{Introduction}

Current health pandemic distress, globalization and liberalisation, existing competition among financial institutions, downsizing and technological advancement over the past decades had caused many changes in the private financial sector, some of which are very damaging such as policy changes due the impacts of the recent and ongoing corornavirus pandemic. Employees of private financial institutions are considered to be amongst the most vulnerable to stress and burn out syndrome (Amigo et al., 2014). The National Health and Morbidity Survey in 2017 as cited by the Institute for Public Health (2017), indicated that nearly $70 \%$ of Malaysian workers were experiencing stress-related illness since the global economic downturn. Dalgaard et al. (2020) examined stress using the transactional perspectives of Lazarus and Folkman (1984) appraisals and defined "stress" as the experience of external demands exceeding personal coping resources. Prior to this, Blonna (2012) had defined stress in terms of the stimuli, constraints, situation or outside forces that places 
extreme demands on peopls, making individuals feel as if they cannot manage. Hence, pyschological hardiness is imperative. High level of psychological hardiness is important because it may increase the individual's commitment to their job (Maryam et al., 2014; Brannon \& Feist, 2010; Beasly et al., 2003; Mehdi and Aubi, 2011; Bartone, et al. 2008).

Stress and employee well-being are related to health and wellness of employee (Khan and Khurshid, 2017). Biggio and Cortese (2013) studied the significant factors attributed to the concept of well-being in the workplace by employees, the influencing factors, and the role of individual psychological characteristics. The results highlight that well-being in the workplace does not depend exclusively on external conditions in terms of the working and organizational environment within which the individual operates. Munusamy and Assim (2019) assert that psychological well-being is as an important personal resource in relation to choosing adaptive coping strategies for stress, particularly academic related stress. Freire's (2016) study focused on transactional model of stress, and stated that coping responses are the key to prevent stress response. In his study, the possible role of psychological well-being as a personal determinant of coping strategies in the academic context was analysed. The findings indicate that the higher the profile of psychological well-being was, the higher the use of the coping strategies. Gender differences in coping strategies were also observed, however no interaction effects with psychological well-being was found.

\section{Literature Review}

Pinquart (2009) analysed whether perceived work-related demands associated with social change. Questions to whether work-related demands were related to psychological wellbeing and regional economic conditions were examined. Higher levels of work-related demands were associated with lower psychological well-being, whereas higher levels of goal engagement in coping with these demands related to higher well-being (Pinquart, 2009). These arguments were further explored by researchers from Malaysia. Ismail et al. (2016) conducted a study on stress level and the common coping strategies and investigated the stress level, and the common coping strategies used by individuals. Coping strategies we found to be not associated to gender, although frequencies on the handling of different copings varied between male and female individuals, with no significant differences in the use of broad coping categories. Ismail et al.'s (2016) study was in line with many other researches that highlight the influence of maladaptive strategies on stress. Nonetheless, other studies indicate that coping strategies did not differ across gender but variation in coping was evident across various groups (Munusamy and Assim, 2019; Dalgaard et al, 2016; Butt, et al., 2018). Studies on moderating roles of coping strategies upon the relationships between psychological constructs are recently being highlighted by orgaizatiional psychologist reseachers (Dalgaard, 2016). Bhagat et al (2010) examined the organizational stress, psychological strain, and work outcomes and the relationship of the moderating roles between factors upon the cultural dimension of individualism-collectivism. The results indicate that problem-focused coping is a better moderator among the individualistic individuals compared to emotion-focused coping is a better moderator among the groups of individuals within collectivistic contexts. The importance of cultural variations and coping with work stress in predicting psychological strain or distress on the job was also highlighted. Moreover, Bashir and Ramay (2010) study had focused on the effects of job stress on employees job performance among employees in Pakistan. Interestingly, a negative correlation between job stress and job performances was found where job stress was found 
to significantly reduce the performance of an individual. A healthy, cooperative and friendly environment within the organization was found to be related to better performances by these financial sector employees.

Oreoluwa and Oludele (2010) researched on the gender factors of stress management techniques among Nigerian financial sectors employees. Male and female employees do not vary significantly in their stress management technique and the authors assert that stress management is not gender sensitive or gender-centric. This is in line with studies from similar work of Bhagat et al. (2010); Dalgaard et al. (2016); Assim et al. (2020); and Munusamy and Assim (2019). However, some recent studies also suggest that both men and women responded differently to an identical achievement related stressor under controlled laboratory conditions. Women reported seeking social support and using emotion concentrated coping method better than men, whereas men were reported using relatively more of problem concentrated coping method than women (Perez-Garin et al., 2017; Owens, et al., 2016; Munusamy and Assim, 2019; Paul and Garg, 2013).

Another study on gender differences in stress and coping indicates that women scored significantly higher than the men in chronic stress and minor daily stressors (Pilar and Matud, 2014). Moreover, women scored significantly higher than men on the emotional and avoidance coping method compared to the lower scores on rational and detachment coping. Men were found to have more emotional inhibition than women, whereas women scored significantly higher than men on somatic symptoms and psychological distress (Matud, et al., 2015; Perez-Garin, 2017; Dalgaard et al., 2014).

Despite the increasing awareness among employers, stress is still a major concern in the workplace. Stress is a global issue and affects all categories of employees in all countries including Malaysia. Coping strategy and psychology hardiness are known factors relating to stress management (Perez-Garin, 2017). Hence, the current study investigated the factor of coping strategy as a moderating effect in predicting psychology hardiness and the outcome of psychology well-being among employees from Malaysian private financial sector. The conceptual framework in Figure 1.0 below displays the interaction effect between psychology hardiness and coping strategy in predicting psychology wellbeing of individuals from various settings.

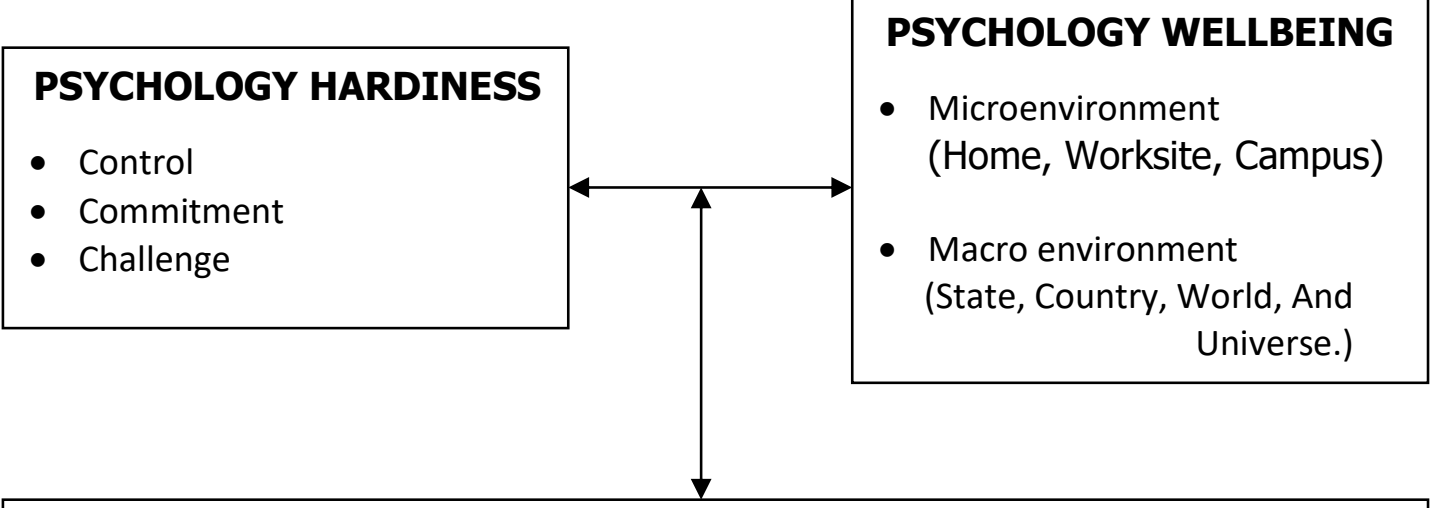


Figure 1.0: Interaction effect between psychology hardiness and coping strategy in predicting psychology wellbeing.

The current study attempts to identify the hardiness factors of individuals from the private financial sector in Malaysia and how they cope with the problem of stress. The types of coping strategies and the moderating effects upon other significant variables. Pertinent issues regarding stress management with effective coping strategy and how to improve the wellbeing of individuals or employees were also discussed.

\section{Methodology}

The current study employed a descriptive and cross-sectional research design. A set of selfadministered questionnaire was developed as the measuring instruments for the purpose of collecting data on psychology hardiness, coping strategy and psychology well-being among private financial institution employees in Malaysia. The demographic questions are aimed at collecting the demographic characteristic of the respondents such as gender, age, race, and their job positions in their workplace. Factor pertaining to psychology hardiness, coping strategy and psychology well-being were measured by the Dispositional Resilience scale, Problem Oriented Brief Coping Experienced (BRIEF COPE) and Well-being Manifestation Measure scale (WBMMS).

In the current study, the conceptual framework as depicted in Figure 2.0 was designed based on the variables psychological hardiness, psychological well-being and the moderating role of coping strategy. This conceptual framework was developed by employing the models from the hardiness theory, holistic health model, and Maddi's hardiness model, and the twocategory model of Brief COPE developed by Meyer et al. which were used in previous studies by Garcia et al. (2018) and Su et al. (2015).

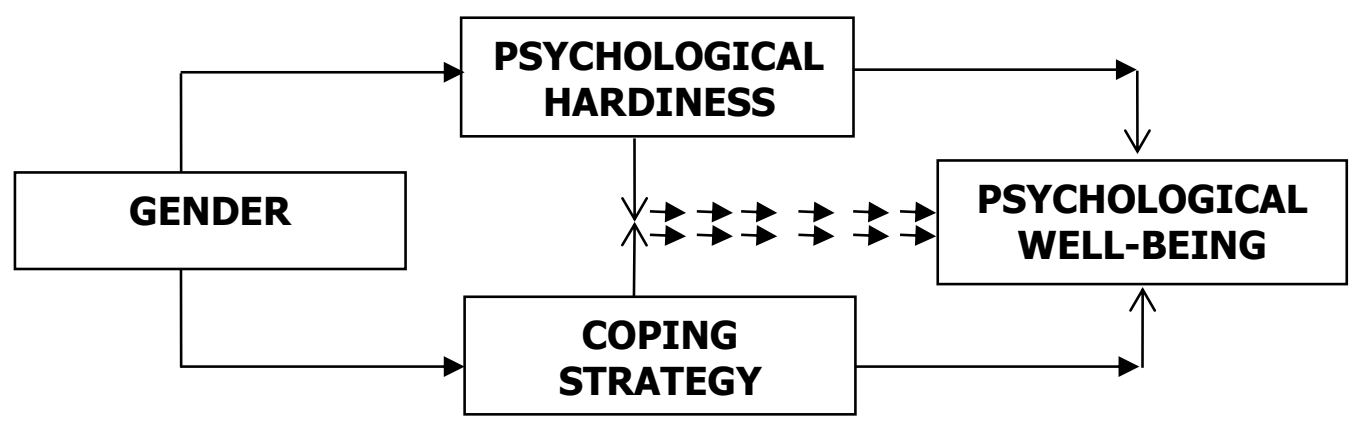




\section{Figure 2.0 Research Framework}

\section{Measurement Instruments}

The Dispositional Resilience [DRS-15 (v3.2)] scale refers to the most recent and up-to-date version of the 15-item Dispositional Resilience Scale (Munusamy and Assim, 2019). The Problem Oriented Brief Coping Experienced (BRIEF COPE) which were proposed by Carver, et al. (1989) was used to measure the the cosntructs coping strategies amog the sampled respondents. The updated version of BRIEF COPE inventory used in the current study refers to the multidimensional coping inventory to measure the different ways in which people respond to stress conditions. The instrument consists of 60 items and 15 scales. Five scales of four items each measure conceptually distinct aspects of problem-focused coping such as active coping, planning, suppression of competing activities, restraint coping, seeking of instrumental social support.

De Lazzari (2000) asserted that the Well-being Manifestation Measure Scale (WBMMS) instrument was first developed by Masse et al. in 1998. The scale contains 25 items with six factors measured on 5 continuum scale from never (1) to almost always (5). The six subscales are control of self/event, happiness, social involvement, self-esteem, mental balance and sociability. WBMMS has demonstrated the high internal consistency of Cronbach alpha of .93 in the pilot stage of the current study, as per depicted in Table 1,0 below.

\begin{tabular}{|l|c|c|c|}
\hline Instrument & \multicolumn{3}{|c|}{ Alpha Value $(\alpha)$} \\
\hline DRS-15 (v3.2) & $\begin{array}{c}\text { Previous } \\
\text { studies }\end{array}$ & $\begin{array}{c}\text { Pilot study } \\
(\mathrm{N}=30)\end{array}$ & $\begin{array}{c}\text { Present study } \\
(\mathrm{N}=141)\end{array}$ \\
\hline BRIEF COPE & .83 & .70 & .74 \\
\hline WBMMS & .79 & .91 & .88 \\
\hline
\end{tabular}

\section{Table 1.0: Reliability of scales}

Source: Data from the original study

Table 1.0 displays the reliability scores (of alpha value) for three research instruments. Previous studies demonstrated the reliability of DRS-15 (v3.2) scale was at the alpha vslues of .83. The instrument of DRS-15 (v3.2) had demonstrated the internal consistency of Cronbach alpha of .70 in the pilot study, .74 for the present study. The BRIEF COPE instrument revealed the internal consistency of Cronbach alpha of .79 in previous studies, while the present study had recorded an internal consistency of Cronbach alpha of .88 The instrument of WBMMS displayed a high internal consistency of Cronbach alpha value of .93 which is identical to the current study.

\section{Samples of the Study}

A sample frame of 141 employees from various private financial institution in a predetermined location in Klang Valley, Malaysia and was obtained by employing a random sampling technique to ensure a sampling distribution which would contribute to the distribution of possible values of the statistic in a population (Glynis et al., 2006). Each respondent was given a questionnaire consisting of three parts, which is Part $A$, contains demographic information, Part B, consists of Psychology Hardiness, Part C, refers to items 
measuring coping strategy while Part D refers to the items on Well-Being Psychology. Respondents were required to answer the questionnaire according to a specified time.

The self-administered questionnaires were returned and the data were complied and analysed using the Statistical Package for Social Sciences (SPSS) program for Windows Version 20. Coping strategy was measured using the Pearson correlation to determine the strength of the relationship between psychology hardiness and psychology wellbeing. Descriptive statistic was used to describe the demographic profiles of sample and Inferential Statistics were used to analyze data and test such as Pearson Correlation Analysis, Independent Sample T-Test, and hierarchical multiple regressions were used to test the moderation effect. Moderation effect was also tested using PROCESS developed by Hayes (2013).

\section{Results}

The demographic analyses of the respondents demographic background such as gender, age race and position in ther workplaces is presented in Table 2.0. This table shows the frequency and percentages of respondent's demographic background.

\begin{tabular}{lcc}
\hline Variables & Frequency $(\mathbf{N}=\mathbf{1 4 1})$ & Percentage (\%) \\
\hline Gender & 52 & 36.9 \\
Male & 89 & 63.1
\end{tabular}

Race

Malay

Chinese

Indian

\section{Age Group}

20-30

\section{Organization*}




$\begin{array}{lcc}\text { PFI_04 } & 11 & 7.8 \\ \text { PFI_05 } & 27 & 19.1 \\ \text { PFI_06 } & 11 & 7.8 \\ \text { PFI_07 } & 8 & 5.7 \\ \text { PFI_08 } & 4 & 2.8 \\ \text { PFI_09 } & 6 & 4.3 \\ \text { PFI_010 } & 5 & 3.5 \\ \text { PFI_011 } & 9 & 6.4\end{array}$

Table 2.0. Frequency and percentages of respondents Demographic Background. *PFI - Private Financial Institution

Source: Data from the original study

Within the total of 141 respondents who took part in the survey, 71 are from ethnic Malays, representing 50.4\%, 31 from the ethnic Malaysian Chinese representing 22\%, and 39 of them are Malaysian Indians representing $27.7 \%$. The majority of participants in this study are females with 89 employees out of 141 employees. Ethnic Malays form the largest group of 71 employees while Chinese Malaysian form the smallest group with 31 employees. The age categorisation displays the age group of 20-30 year-olds make up the majority of the samples, with $77.3 \%$ or 109 employees while respondents between the age group of 31-40 year-olds comprise of the second largest group of $26.6 \%$ or 29 employees followed by respondents between the age group of $41-50$ year-olds, with $2.1 \%$ or 3 employees only. The number of participants from PFI_01 is 24 or $17 . \%$ while participants from PFI_02 is 19 or $13.5 \%$. The number of participants from PFI_03 is 17 or $21.1 \%$. The number of participants from PFI_04 numbered at 11 employees or $7.8 \%$ and from PFI_05 is 27 employees or $19.1 \%$. The number of participants from PFI_06 is 11 employees or $7.8 \%$ while from PFI_07 is 8 employees or $5.7 \%$. The number of participants from PFI_08 is 9 employees or $6.4 \%$ while from PFI_09 is 5 employees or 3.5\%, and from PFI_010 is 6 employees or $4.3 \%$. The number of participants from PFI_011 formed the smallest group out of the total 141 participants at 4 employees or 2.8\%. Participants from PFI_01 form the largest group while participants from PFI_02 form the second largest group.

Psychology Hardiness

Psychology Wellbeing
Pearson correlation

.316
Sig . (2 tailed)

**. Correlation is significant at the 0.01 level (2-tailed).

TABLE 3.0: Correlation between Psychology Hardiness and Psychology well-being Source: Data from the original study

Analyses on the correlation between variable yielded that the construct of psychology hardiness was positively correlated with psychology well-being (see Table 3.0). The results of correlation analysis showed a correlation between psychology hardiness of employees and their psychology well-being is significant $(r=.316, n=141, p<.001)$. The result indicates that the high level of employees' psychology hardiness increases their well-being. 


\begin{tabular}{lcc}
\hline Wellbeing & Pearson correlation & Sig . (2 tailed) \\
\hline Adaptive coping strategies & & $.000^{* *}$ \\
\hline Active & .456 & $.000^{* *}$ \\
Planning & .535 & $.000^{* *}$ \\
Suppression & .302 & $.001^{* *}$ \\
Instrumental & .271 & $.008^{* *}$ \\
Emotional & .224 & $.000^{* *}$ \\
Positive & .444 & $.001^{* *}$ \\
Acceptance & .289 & $.000^{* *}$ \\
Religion & .326 & $.013^{*}$ \\
Humour & .210 & .532 \\
\hline Maladaptive coping strategies & & .875 \\
\hline Denial & .053 & .882 \\
Venting & .013 & .364 \\
Behaviour & -.013 & .094 \\
Mental & .077 & \\
Substance & .142 & \\
$* *$ Correlation is significant at the 0.01 level (2-tailed). & \\
*. Correlation is significant at the 0.05 level (2-tailed). &
\end{tabular}

TABLE 4.0: Correlation between Coping strategy and Psychology well-being Source: Data from the original study

The results as diplayed in Table 4.0 above shows that correlation between adaptive coping strategies and psychology well-being are positive. The results of correlation analysis showed a correlation between psychology hardiness and coping strategy are significant at the 0.01 level, accordingly with active coping $(r=.456, n=141, p<.001)$, planning $(r=.535, n=141, p$ $<.001)$, suppression of competing activities $(r=.302, n=141, p<.001)$, seeking of instrumental social support $(r=.271, n=141, p<.001)$, emotional $(r=.224, n=141, p<.001)$, positive $(r=$ $.444, n=141, p<.001)$, acceptance $(r=.289, n=141, p<.001)$, and religion $(r=.326, n=141$, $p<.001)$. However, the correlation between psychology hardiness and humour scale indicate a significant relationship, at the 0.05 level (two-tailed) as $(r=.210, n=141, p<.005)$. The results of correlation analysis show that maladaptive coping strategies which are denial, venting, behaviour, mental and substance are not correlated with psychology well-being.

\begin{tabular}{lllllllll}
\hline P.H & $\mathrm{n}$ & Mean & $\mathrm{SD}$ & $\mathrm{T}$-cal & T-crit & $\mathrm{df}$ & $\mathrm{p}$ & Decision \\
\hline Male & 52 & 29.06 & 6.415 & -.828 & & 139 & .409 & Reject \\
\hline Female & 89 & 29.90 & 5.444 & & & & & \\
\hline
\end{tabular}

TABLE 5.0: $t$-test Results Comparing Males and Females on Psychology Hardiness . Source: Data from the original study

An independent-samples t-test was conducted to compare gender within the relationship with psychology hardiness variable. There was no significant difference in the scores for psychology hardiness variables between male $(M=29.06, S D=6.415)$ and female $(M=29.90$, $\mathrm{SD}=5.444)$ conditions; $\mathrm{t}(139)=-0.828, \mathrm{p}=.409$. There is an estimated change of $-.828 \%$ (SE $=1.016 \%)$. However, no sufficient evidence was found to $(P=.409)$ to suggest that there is a difference between psychology hardiness and gender variables. 


\begin{tabular}{lllllllll}
\hline P.H & $\mathrm{n}$ & Mean & SD & T-cal & T-crit & df & P & Decision \\
\hline Male & 52 & 161.31 & 21.710 & -.303 & & 139 & .762 & Reject \\
\hline Female & 89 & 162.37 & 19.097 & & & & & \\
\hline
\end{tabular}

TABLE 6.0: $t$-test Results in Comparing Males and Females on Coping Strategy.

Source: Data from the original study

An independent-samples t-test was conducted to compare gender in the relationships of coping strategy variable. There was no significant difference in the scores for coping strategy between male $(M=161.31, S D=21.710)$ and female $(M=162.37, S D=19.097)$ conditions; $\mathrm{t}(139)=-0.303, \mathrm{p}=.762$ ". There is an estimated change of $-1.063 \%$ (SE $=3.508 \%)$. However, there is no sufficient evidence $(P=0.762)$ to suggest that there is a difference between coping strategy and gender.

Model Summary

\begin{tabular}{|c|c|c|c|c|c|c|c|c|c|}
\hline \multirow[t]{2}{*}{ Model } & \multirow[t]{2}{*}{$R$} & \multirow{2}{*}{$\begin{array}{c}\mathrm{R} \\
\text { Square }\end{array}$} & \multirow{2}{*}{$\begin{array}{l}\text { Adjusted } \\
\text { R Square }\end{array}$} & \multirow{2}{*}{$\begin{array}{c}\text { Std. Error } \\
\text { of the } \\
\text { Estimate }\end{array}$} & \multicolumn{5}{|c|}{ Change Statistics } \\
\hline & & & & & $\begin{array}{c}\text { R Square } \\
\text { Change }\end{array}$ & \begin{tabular}{|c|}
$F$ \\
Change
\end{tabular} & $\mathrm{df1}$ & $\mathrm{df} 2$ & $\begin{array}{c}\text { Sig. F } \\
\text { Change }\end{array}$ \\
\hline 1 & $10^{\circ}$ & .100 & .094 & 13.516 & .100 & 15.449 & 1 & 139 & .000 \\
\hline 2 & $.385^{b}$ & .148 & .136 & 13.197 & .048 & 7.797 & 1 & 138 & .006 \\
\hline
\end{tabular}

a. Predictors: (Constant), $\mathrm{PH}$

b. Predictors: (Constant), PH, Interaction Cope\&PH

TABLE 7.0: Interaction between Coping strategy and psychology

Source: Data from the original study

ANOVA $^{\mathrm{a}}$

\begin{tabular}{|rl|r|r|r|r|r|}
\hline \multicolumn{2}{|l|}{ Model } & \multicolumn{1}{c|}{$\begin{array}{c}\text { Sum of } \\
\text { Squares }\end{array}$} & Df & \multicolumn{1}{c|}{$\begin{array}{l}\text { Mean } \\
\text { Square }\end{array}$} & F & Sig. \\
\hline \multirow{2}{*}{1} & Regression & 2822.195 & 1 & 2822.195 & 15.449 & $.000^{\mathrm{b}}$ \\
& Residual & 25392.273 & 139 & 182.678 & & \\
& Total & 28214.468 & 140 & & & \\
& Regression & 4180.084 & 2 & 2090.042 & 12.001 & $.000^{c}$ \\
& Residual & 24034.384 & 138 & 174.162 & & \\
& Total & 28214.468 & 140 & & & \\
\hline
\end{tabular}

a. Dependent Variable: PWB

b. Predictors: (Constant), $\mathrm{PH}$

c. Predictors: (Constant), PH, Interaction Cope\&PH

TABLE 8.0: ANOVA Tests

Source: Data from the original study 
Model 2 with the interaction between Coping strategy and psychology hardiness accounted for significantly more variance, compared to coping strategy and psychology hardiness, R2 change $=.048, p=.006$, indicating that there is potentially significant moderation between coping strategy and hardiness on psychology wellbeing. These variables accounted for a significant amount of variance in psychology well-being, $R 2=.100, F(1,139)=15.45, p<.001$. The means of the two predictors wee adjusted to zero value by the predictors being centred or standardised. The two predictors has been entered in the first step (block 1) of the hierarchical multiple regressions while the interaction in the second step (block 2). According to Howitt \& Cramer (2011), there is a moderating effect if the interaction explains a significant amount of the variance in the criterion. Furthering the analyses, the interaction term between coping strategy (adaptive coping strategies only) and psychology hardiness was added to the regression model, which accounted for a significant proportion of the variance in employees' well-being, $\Delta R 2=.100, \Delta F(1,138)=7.797, p=.001, b=-.007, t(137)=-1.326, p<.01$. Examination of the interaction plot showed an enhancing effect that as coping strategy (adaptive coping strategies only) and psychology hardiness increased, employees' wellbeing also increased. To interpret the significant interaction three separate unstandardized regression lines were plotted between standardized psychology hardiness, standardized coping strategy and the standardized level of psychology well-being at the mean and at one standard deviation above and below and well-being strongest at a high level of coping strategy.

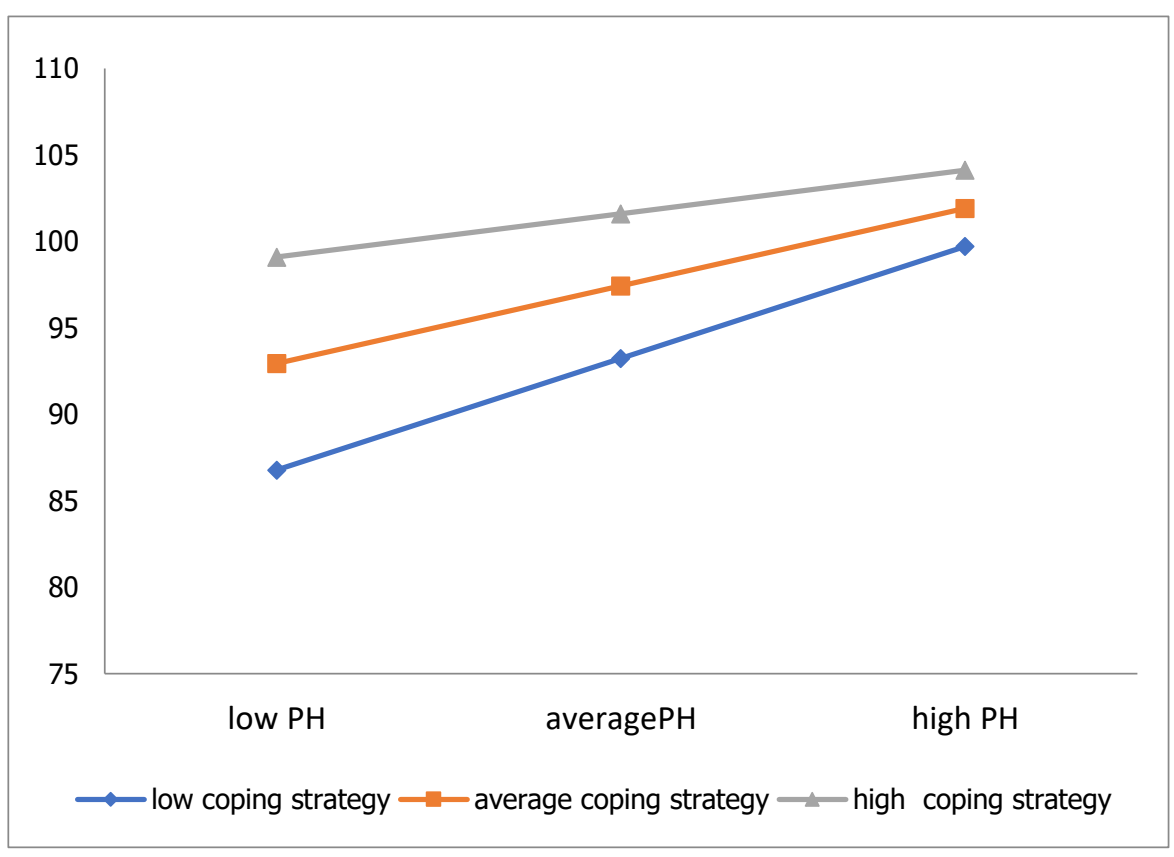

Chart 1.0 Chart plot of the interaction of the unstandardized regression lines Source: Data from the original study

Overall the results show that the interaction plot showed in Chart 1.0 displays an enhancing effect that as coping strategy (adaptive coping strategies only) and psychology hardiness increased, employees' wellbeing also increased. At low effect of psychology hardiness, employees' psychology wellbeing was similar for ineffective coping strategy. As for employees from high psychology hardiness effect, they display a high coping strategy that is in line with their high values on wellbeing. This result indicate that the findings of the current study is 
supportive of previous studies with similar constructs and variables (Dalgaard, 2017; PerezGarin 2016).

\section{Discussions}

A correlation between psychology hardiness and psychology well-being was hypothesised in the current study. The Pearson correlation results showed a correlation between psychology hardiness of employees and their psychology well-being is significant. The result indicatess that the high level of employees' psychology hardiness increased their well-being such as control of self/event, happiness, social involvement, self-esteem, mental balance and sociability. Based on this current research finding, the hypothesis is accepted which shows significant value as $r=.316, n=141, p<.001$ ). Based on Malek et al. (2009), occupational stress had significant reverse correlations with job satisfaction and well-being. While, coping strategies and work motivation are shown to be one of the potential moderating variables which is supported by the findings of this research. Another study by Soderstrom et al (2000), shows that higher level of hardiness in corporate and university samples have a lower level of stress and fewer symptoms of illness. The current findings also supports the findings by Azeem (2010); Butt el al. (2020); Pengilly and Dowd (2000), which indicates that stress was significantly correlated with the hardiness scale of commitment and control. It was also stated that individuals with high stress, the low commitment had higher scores on the Beck Depression Inventory (BDI) while the low stress has the opposite score. Results in this study is also supported by Seok, Hashmi, and Chiew (2012), which indicates that an individual who is competent in managing their internal states, impulses, and resources, have less mental health problems. Moreover, the current study reveals that psychological hardiness and high social support directly have an impact on the measures of psychological and somatic distress which is similar to the findings done by Kanika Kindal (2013). In addition, the results from the current study are in line with the findings of Paul, Robert, James, and Thomas (2008), which found that psychological hardiness appears to be a key individual characteristic related to stress tolerance and successful performance in a very demanding occupation.

Another assumption and hypothesis in the current study was that there is a correlation between Coping strategy and psychology well-being. The result of the current study indicates a correlation with a significant relationship between psychology hardiness and coping strategy, with adaptive coping strategies was the only one to be significant. However, there is no correlation between maladaptive coping strategies and psychology well-being. Aniza Ismail, Sana Taher Ashur, etc. (2016) claims the adaptive coping scale tended to be correlated with the desirable outcome and would have lower levels of psychological distress. Maladaptive coping strategy (self-distraction, self-blame and denial) had been proven to be an important association to stress. However, the present study shows that there is no significant relationship with the maladaptive coping strategy. Mohd Zukri \& Noor Hassim (2010) and other authors (Aldwin, 2007; Aniza et al, 2016; Bhagat et al., 2010; Blona, 2012) stress that positive reframing and emotional support are the coping strategies that have a significant effect in reducing stress symptoms.

As gender was one of the main variables under study, the results indicate that there was no significant differences between psychology hardiness and gender, even there is an estimated change of $-1.063 \%$ ( $S E=3.508 \%)$. However, there is insufficient evidence $(P=0.762)$ to suggest that there is a significant difference between coping strategy and gender. Furthermore, an 
independent-samples t-test and the overall findings clearly shows that there is no impact on coping strategy contributed to gender. There was no significant difference in the scores for coping strategy between male $(M=161.31, S D=21.710)$ and female $(F=162.37, S D=19.097)$ conditions; $\mathrm{t}(139)=-0.303, \mathrm{p}=.762$. The result of this study does support the finding of previous studies conducted by Aniza Ismail, Sana Taher, etc. (2016), which asserts that no impact on the coping strategies can be contributed to gender. Nonetheless, there are few studies that supports finding for the present study. According to Soderstrom, Dolbier, Leiferman, \& Steinhardt (2000), their results on examining gender differences for both sample using the multiple-group model shows that there is no significant difference in the relationship of hardiness, coping strategies, and perceived stress to symptoms of illness. While, Bhagat, Krishnan, Nelson, Leonard, Leonard, Ford, et al. (2010), also found that male and female employees do not vary significantly in their stress management technique and that stress management is not gender sensitive or gender- centric.

As for another assumption of whether coping strategy as a moderator would increase the effect of psychological hardiness on employees' well-being in the financial sector, a hierarchical multiple regression analysis was conducted. Examination of the interaction plot showed an enhancing effect that as coping strategy (adaptive coping strategies only) and psychology hardiness increased, employees' wellbeing also increased. At low psychology hardiness, employees' psychology wellbeing was similar for ineffective coping strategy. Employees from high psychology hardiness, displayed effective coping strategy that had the good outcome on their wellbeing. Azeem (2010) stressed that the correlation analyses of his study indicated significant relationships between hardiness dimensions and job involvement. Studies had found that hardiness has beneficial main effects in reducing burnout (Butt, 2018). It can be postulated that that employees have lower burnout because of their ability to deal with the multifarious problems of their job requirements and other types of problems effectively and efficiently. Conclusively Norris et al. (2017) and Azeem's (2010) and Butt's (2018) with other authors (Bashir e al., 2010; Van de Voorde e al., 2012; Carlos, et al., 2016; Carver et al., 1989; ; Carver et al., 1990; Folkman et al, 1986) findings are similar to findings in the current study (as detailed in Munusamy and Assim, 2019 and supported by the studies of Soderstrom, Dolbier, Leiferman, \& Steinhardt, 2000) and Malek et al., 2013). The current study also found a significant influence of coping behaviour as a moderating variable on job satisfaction as the result indicated that overall coping behaviour has a significant influence on overall job satisfaction. This is suooirted by Bhagat, Krishnan, Nelson, Leonard, Leonard, Ford, et al. (2010) who argues that problem-focused coping is a better moderator in the individualistic countries and that emotion-focused coping is a better moderator in the collectivistic contexts.

\section{Conclusion}

This study concluded that there is a relationship between psychology hardiness, psychology well-being, gender and the moderating effect of coping strategy. It had identified significant predicting variable of psychology well-being. The reviewed literature was also supported by empirical research and relevant theories and models on these areas in order to determine the nature of the relationship between psychology hardiness, psychology well-being, gender and coping strategy. The survey was conducted at 11 private financial institutions in Klang Valley, Malaysia from 141 respondent which includes both local and the international financial institutions. 
The result of the current study indicated that there was significant relationship between psychology hardiness, coping strategy (adaptive coping strategies only) and psychology wellbeing. However, there is no significant difference in the scores for coping strategy between male and female. The result of this study does support the finding of previous studies conducted by Aniza Ismail, Ismail e al. (2016), which found out that no impact on the coping strategies can be contributed to gender. In addition, $T$ test analyzes the differences in gender and Psychology hardiness and the results showed that there were significant differences between psychology hardiness and gender have not a significant relationship. The Pearson correlation results showed a correlation between psychology hardiness of employees and their psychology well-being is significant. The result explains that the high level of employees' psychology hardiness increases their well-being such as control of self/event, happiness, social involvement, self-esteem, mental balance and sociability. Moreover, the result indicates a correlation between psychology hardiness and coping strategy which is adaptive coping strategies, which is the only one which is proven to be significant. However, there is no correlation between maladaptive coping strategies and psychology well-being in the current study.

A hierarchical multiple regression analysis was also conducted. Examination of the interaction plot showed an enhancing effect that as coping strategy (adaptive coping strategies only) and as psychology hardiness increased, employees' wellbeing would also increased. At low psychology hardiness, employees' psychology wellbeing was similar for ineffective coping strategy. As for employees with high psychology hardiness, they had effective coping strategy which contributed to the good outcome on their wellbeing. This study concludes that coping strategy (active coping strategy only) enhances the effect of psychology hardiness on wellbeing. When psychology hardiness is high, but the coping strategy is low, it is proposed that the wellbeing of an individual is assumed to be low. However when both psychology hardiness and coping strategy is high, then is is proposed that the wellbeing will also be high due to the enhancing effect of coping strategy within the individual.

\section{Limitation and Suggestions for Future Research}

The current study had focused on the employee's personality, coping strategy, gender and wellbeing, which relate to stress, rather than the stressor itself. The limitation of the current study is that it does not measure what factors that causes stress among employees in the private financial institution sector. Furthermore, only active coping strategies were included in the moderation test. The maladaptive coping strategies were not included in the hierarchical multiple regressions test. According to Live Events Theory which emphasized on stressful experience, stress level and available resources of stressors, studies on stress and its contributing factors are are feasible to aby level of reseaches. However, due to limitations of funding, time and logistic reasons, the emphasis on how hardy the person is, coping strategy and their wellbeing or stressful experiences were not measured. Therefore, for future studies, the severity of stress level and the number of stressful events and the experiences of stress of the individuals should be taken into consideration. In addition, further studies may focus on more employment sectors and should also include a wide range of sampling backgrounds.

\section{Acknowledgement}

The author would like to acknowledge all teachers and individuals involved in the data gathering for their help and generous support.

\section{References}


Abid, G., \& Butt, T. H. (2017). Expressed turnover intention: Alternate method for knowing turnover intention and eradicating common method bias. International Letters of Social and Humanistic Sciences, 78, 18-26.

Aiken, L. S., \& West, S. G. (1991). Multiple regression: Testing and interpreting interactions. Thousand Oaks, CA: Sage.

Aldwin, C. M. (2007). Stress, coping, and development: an integrative perspective. 2nd ed. (pp 161). New York: The Guildford Press

Andrew, F. H. (2013). Introduction to Mediation, Moderation, and Conditional Process Analysis: A Regression-based Approach. 1st ed. New York: The Guilford Press.

Annabel, N. E., Bryan J. R. (2011). Methods in psychological Research. 2nd edition. SAGE Publications,inc: United States. Pages 122- 124.

Atwater, L., \& Carmeli, A. (2009). Leader-member exchange, feelings of energy and involvement in creative work. The Leadership Quarterly, 20(3), 264-275.

Azeem, S. M. (2010). Personality hardiness, job involvement and job burnout among teachers. International Journal of Vocational and Technical Education, 2(3), 36 - 40.

Bakker, A. B., \& Sanz-Vergel, A. I. (2013). Weekly work engagement and flourishing: The role of hindrance and challenge job demands. Journal of Vocational Behavior, 83(3), 397-409.

Baptiste, N. R. (2008). Tightening the link between employee wellbeing at work and performance: A new dimension for HRM. Management Decision, 46(2), 284-309.

Bashir, U., \& Ramay, M. I. (2010). Impact of stress on employees' job performance a study on banking sector of Pakistan. International Journal of Marketing Studies, 2(1), 122126.

Bergeron, D. M., Shipp, A. J., Rosen, B., \& Furst, S. A. (2013). Organizational citizenship behavior and career outcomes: The cost of being a good citizen. Journal of Management, 39(4), 958-984.

Berglund, V., Sevä, I.J., \& Strandh, M. (2016) Subjective well-being and job satisfaction among self-employed and regular employees: does personality matter differently? Journal of Small Business \& Entrepreneurship, 28(1), 5573, DOI: $10.1080 / 08276331.2015 .1115699$

Bhagat, R. S., Krishnan, B., Nelson, T. A., Leonard, T. A., Leonard, K. M., Ford Jr, D. L., et al. (2010). Organizational stress, psychological strain, and work outcomes in six national contexts. Cross Cultural Management: An International Journal, 10-29.

Bhimwal, N. (2007). Understanding well-being: An exploratory study of life without death. In R. Singh, \& R. Shyam (Eds.), Psychology of Well-being (pp. 373-379). New Delhi: Global Vision Publishing House.

Blonna, R. (2012). Coping with stress in a changing world. 5th ed. (pp 7, 8, 77). New York: Mcgraw-Hill.

Bolino, M. C., \& Grant, A. M. (2016). The bright side of being prosocial at work, and the dark side, too: A review and agenda for research on other-oriented motives, behavior, and impact in organizations. Academy of Management Annals, 10(1), 599-670.

Bono, J. E., Davies, S. E., \& Rasch, R. L. (2012). Some traits associated with flourishing at work. In K. S.Cameron \& G. M. Spreitzer (Eds.), The Oxford handbook of positive organizational scholarship (pp.125-137). New York, NY: Oxford.

Bordens. k. s. (2014). Research design and Methods: A process Approach. 9th ed. (pp.161). New York: Mcgraw-Hill. 
Boyd, C. M., Tuckey, M. R., \& Winefield, A. H. (2013). Perceived effects of organizational downsizing and staff cuts on the stress experiences: The role of resources. Stress Health, doi: 10.1002/smi.2495

Brannon, L., \& Feist, J. (2010). Health psychological: An introduction to behaviour and health. 7th ed. (pp 121,). USA: Wadsworth,Cengage Learning.

Breakwell, G. M., Hammond, S., Fife-Schaw, C., \& Smith, J. A. (2006). Research Methods in Psychological. 3rd ed. (pp 90). London: SAGE Publication Ltd.

Butt, T. H., Abid, G., Arya, B., \& Farooqi, S. (2020) Employee energy and subjective well-being: a moderated mediation model.The Service Industries Journal, 40 (12), 133-157 DOI: 10.1080/02642069.2018.1563072

Calvard, T. S., \& Sang, K. J. (2017). Complementing psychological approaches to employee well-being with a socio-structural perspective on violence in the workplace: An alternative research agenda. The International Journal of Human Resource Management, 28(16), 2256-2274.

Carlos. F., María. D., Mar F., Antonio V., José C. N., \& Guillermo V., (2016). Profiles of Psychological Well-being and Coping Strategies among University Students. Frontiers in Psychology. Published online 2016 Oct 13. doi: 10.3389/fpsyg.2016.01554).

Carver, C. S. (2013). Brief COPE . Measurement Instrument Database for the Social Science. Retrieved from www.midss.ie

Carver, C. S., \& Scheier, M. F. (1990). Origins and functions of positive and negative affect: A control process view. Psychological Review, 97(1), 19-35.

Carver, C. S., Scheier, M. F., \& Weintraub, J. K. (1989). Assessing coping strategies: A theoretically based approach. Journal of Personality and Social Psychological, 56, 267283.

Chen, H., Cheng, H., Zhu, D., \& Long, R. (2016). Dimensions of employee energy and their differences: Evidence from Chinese insurance companies. Human Factors and Ergonomics in Manufacturing \& Service Industries, 26(6), 740-753.

Clawson, J. G., \& Haskins, M. E. (2000). Beating the career blues. The Academy of Management Executive, 14(3), 91-102.

Dalgard, C.-J., Strulik, H. (2014). The Economics of Health Demand and Human Aging: Health Capital vs. Health Deficits, Discussion Paper, University of Goettingen. (Retrieved from http://holger-strulik.org/my_papers/health_capital_deficits.pdf).

Dawson, C., Veliziotis, M., \& Hopkins, B. (2017). Temporary employment, job satisfaction and subjective well-being. Economic and Industrial Democracy, 38(1), 69-98.

De Dreu, C. K. (2006). Rational self-interest and other orientation in organizational behavior: A critical appraisal and extension of Meglino and Korsgaard 2004. Journal of Applied Psychology, 91(6), 1245-1252.

De Lazzari, S. A. (2000). Emotional Intelligence, meaning, and Psychological Wellbeing: A Cmparison between early and late adolescence. Meaning and Psychological Well-being. 1-107

Diedericks, E., \& Rothmann, S. (2013). Flourishing of information technology professionals: The role of work engagement and job satisfaction. Journal of Psychology in Africa, 23(2), 225-233.

Diener, E. (2012). New findings and future directions for subjective well- being research. American Psychologist, 67(8), 590-597. 
Diener, E., \& Chan, M. Y. (2011). Happy people live longer: Subjective well-b eing contributes to health and longevity. Applied Psychology: Health and Well-Being, 3(1), 1-43.

Diener, E., Wirtz, D., Tov, W., Kim-Prieto, C., Choi, D. W., Oishi, S., \& Biswas-Diener, R. (2010). New wellbeing measures: Short scales to assess flourishing and positive and negative feelings. Social Indicators Research, 97(2), 143- 156.

Evans. A. E., \& Rooney, B. J. (2008). Methods in Psychological research. (pp 108). London: SAGE Publications Ltd.

Fan, D., Cui, L., Zhang, M. M., Zhu, C. J., Härtel, C. E., \& Nyland, C. (2014). Influence of highperformance work systems on employee subjective well- being and job burnout: Empirical evidence from the Chinese healthcare sector. The International Journal of Human Resource Management, 25(7), 931-950.

Field, A. (2013). Discovering statistics using SPSS. LONDON: Sage Publications.

Folkman, S., Lazarus, R. S., Dunkel-Schetter, C., DeLongis, A., \& Gruen, R. J. (1986). Dynamics of a stressful encounter: Cognitive appraisal, coping, and encounter outcomes. Journal of Personality and Social Psychology, 50, 992-1003.

Fornell, C., \& Larcker, D. F. (1981). Evaluating structural equation models with unobservable variables and measurement error. Journal of Marketing Research, 18(1), 39-50.

Frederick, J. G., \& Lori-Ann, B. F. (2006). Research Methods for behavioral sciences. Second edition. United States of America: Vicki Knigt. Pages 12-130.

Fredrickson, B. L., \& Losada, M. F. (2005). Positive affect and the complex dynamics of human flourishing. American Psychologist, 60(7), 678-686.

Fritz, C., Lam, C. F., \& Spreitzer, G. M. (2011). It's the little things that matter: An examination of knowledge workers' energy management. The Academy of Management Perspectives, 25(3), 28-39.

Gable, S. L., Reis, H. T., Impett, E. A., \& Asher, E. R. (2004). What do you do when things go right? The intrapersonal and interpersonal benefits of sharing positive events. Journal of Personality and Social Psychology, 87(2), 228-245.

George, D., \& Mallery, P. (2012). IBM SPSS statistics 19 step by step A simple guide and reference (12th ed.). Boston: Pearson.

Gharehzad A. M., Ghorban. S. S., Khalatbari. J, (2013). Effectiveness of Hardiness Training on Anxiety and Quality of Life of Pregnancy Women. Procedia - Social and Behavioral Sciences. Volume 84, 9 July 2013, Pages 1785-1789).

Gilbreath, B., \& Benson, P. G. (2004). The contribution of supervisor behaviour to employee psychological well-being. Work \& Stress, 18(3), 255-266.

Glynis, M. B., Sean, H., Chris, F. S., \& Jonathan, A. S. (2006). Research Methods In Psychological. 3rd ed. (pp.391). London: SAGE Publications Ltd.

Golparvar, M., Kamkar, M., \& Javadian, Z. (2012). Moderating effects of job stress in emotional exhaustion and feeling of energy relationships with positive and negative behaviors: Job stress multiple functions approach. International Journal of Psychological Studies, 4(4), 99-112.

Goodwin, C. J. (2010). Research in Psychological: Methods and Design. 6th ed. (pp. 141). USA: Mcgraw-Hill.

Graen, G. B., \& Uhl-Bien, M. (1995). Relationship-based approach to l eadership: Development of leader member exchange (LMX) theory of leadership over 25 years: Applying multi-level multidomain perspective. The Leadership Quarterly, 6(2), 219-247.22 T. H. BUTT ET AL. 
Grant, A. M., \& Berry, J. W. (2011). The necessity of others is the mother of invention: Intrinsic and prosocial motivations, perspective taking, and creativity. Academy of Management Journal, 54(1), 73-96.

Hair, J. F., Hult, G. T. M., Ringle, C. M., \& Sarstedt, M. (2017). A primer on partial least squares structural equation modeling (PLS-SEM) (2nd Ed). Thousand Oaks, CA: Sage.

Hakanen, J. J., \& Schaufeli, W. B. (2012). Do burnout and work engagement predict depressive symptoms and life satisfaction? A three-wave seven-year prospective study. Journal of Affective Disorders, 141(2), 415-424.

Hakanen, J. J., Peeters, M. C. W., \& Schaufeli, W. B. (2017). Different types of employee well-being across time and their relationships with job crafting. Journal of Occupational Health Psychology. Advance online publication.

Hershcovis, M. S., Turner, N., Barling, J., Arnold, K. A., Dupré, K. E., Inness, M., ... Sivanathan, N. (2007). Predicting workplace aggression: A meta-analysis. Journal of Applied Psychology, 92(1), 228-238.

Howitt. D., \& Cramer. D. (2011). Introduction to SPSS Statistics in Psychology: for version 19 and earlier. 5th ed. (pp 68, 350 \& 465). Harlow: Pearson Education Limited. Institute for Public Health. (2017). National Health and Morbidity Survey (NHMS) 2017: Volume 1: Methodology and General Findings. Ministry of Health Malaysia.

Ismail, A., Ashur, S. T., Jamil, A.T., Lee, C. W., \& Mustafa, J. (2016). Stress Level and The Common Coping Strategies Among International Postgraduate Students At University Kebangsaan Malaysia Medical Centre (UKMMC), Cheras, Kuala Lumpur, Malaysia. ASEAN Journal of Psychiatry, 17(1).

Judge, T. A., Thorensen, C. J., Bono, J. E., \& Patton, G. K. (2001). The job satisfaction-job performance relationship: A qualitative and quantitative review. Psychological Bulletin, 127(3), 376-407.

Karademas, E. C. (2006). Self-efficacy, social support and well-being: The mediating role of optimism. Personality and Individual Differences, 40(6), 1281-1290.

Keyes, C. L. (2014). Happiness, flourishing, and life satisfaction. The Wiley Blackwell Encyclopedia of health, illness, behavior, and society. In W. R. Cockersham, R. Dingwell, \& S. R. Quah (Eds.), The WileyBlackwell encyclopedia of health, illness, behavior, and society (pp. 747- $\quad$ 751). London: Wiley.

Kuykendall, L., \& Tay, L. (2015). Employee subjective well-being and

physiological functioning: An integrative model. Health Psychology Open, 2(1), 1-11.

Lee, R. T., Seo, S., Hladkyj, S., Lovell, B. L., \& Schwartzmann, L. (2013). Correlates of physician burnout across regions and specialties: A meta-analysis. Human Resources for Health, $11,48-90$

Li, M., Taylor, E. G., Atkins, K. E., Chapman, G. B., \& Galvani, A. P. (2016). Stimulatinginfluenza vaccination via prosocial motives. PloS One, 11(7), e0159780.

Luke A. N., Faye F. D., Mariana K., (2017). Stressors, coping, and well-being among sports coaches: A systematic review. Psychology of Sport and Exercise. Volume 33, November 2017, Pages 93-112).

Malik, M. A. R., Butt, A. N., \& Choi, J. N. (2015). Rewards and employee creative performance: Moderating effects of creative self-efficacy, reward importance, and locus of control. Journal of Organizational Behavior, 36(1), 59-74. 
Margaret B., Ted T., John D., (2003). Resilience in response to life stress: the effects of coping style and cognitive hardiness. Personality and Individual Differences Volume 34, Issue 1, January 2003, Pages 77-95)

Masse, R., Poulin, C., Dassa, C., Lambert, J., Belair, S., \& Battaglini, A. (1998). The structure of mental health higher-order confirmatory factor analyses of psychological distress and well-being measures. Social Indicators research, 45, 475-504.

Matud, M. P., Bethencourt, J. M., \& Ibáñez, I. (2015). Gender differences in psychological distress in Spain. International Journal of Social Psychiatry, 61(6), 560-568. https://doi.org/10.1177\%2F0020764014564801

Meglino, B. M., \& Korsgaard, A. (2004). Considering rational self-interest as a disposition: Organizational implications of other orientation. Journal of Applied Psychology, 89(6), 946-959.

Menges, J. I., Tussing, D. V., Wihler, A., \& Grant, A. M. (2017). When job performance is all relative: How family motivation energizes effort and compensates for intrinsic motivation. Academy of Management Journal, 60(2), 695-719.

Malek, M. D., \& Mohd Kamil, I. S. (2013). The Moderating Effect of Coping Strategies on Job Satisfaction and Psychological Well Being Among Fire Fighters. The Asian Conference on Psychological \& the Behavioral Sciences, 249-262

Malek, M. D., Adi, F. \& Kamil, M. I.S. (2009). Occupational Stress and Psychological Well-being in Emergency Service. Asian Social Work and Policy Review Journal: United State: John Willey and Sons.

Monnot, M. J., \& Beehr, T. A. (2014). Subjective well-being at work: Disentangling source effects of stress and support on enthusiasm, contentment, and meaningfulness. Journal of Vocational Behavior, 85(2), 204-218.

Munusamy, A., \& Assim, M.I.S.A. (2019). Psychology Hardiness and Psychology Well-Being of Banking Sector Employees and Moderating Role of Coping Strategy. Journal of Social Sciences and Humanities, 16(1), 1-13.

Nielsen, K., Nielsen, M. B., Ogbonnaya, C., Känsälä, M., Saari, E., \& Isaksson, ～K. ～(2017). Workplace resources to improve both employee well-being and performance: $A$ systematic review and meta- analysis. Work \& Stress, 31(2), 101-120.

Oreoluwa, A. R., \& Oludele, A. A. (2010). Occupational stress and the Nigerian banking industry. Journal $f$ Economics and Enguneering, 14- 21

Owens, B. P., Baker, W. E., Sumpter, D. M., \& Cameron, K. S. (2016). Relational energy at work: Implications for job engagement and job performance. Journal of Applied Psychology, 101(1), 35-49.

Pagano, R. P. (2010). Understanding Statistics in the behavioral sciences. 9th ed. (pp. 114). USA: Wadsworth.

Paul, H., \& Garg, P. (2013). Tendency to display citizenship behaviours at work: Role of subjective wellbeing. Indian Journal of Health and Wellbeing, 4(1), 16-20.

Paul. T. B., Robert R. R., James J.P., \& Thomas J. W. (2008). Psychological HardinessPredicts Success in US Army Special Forces Candidates. International Journal of Selection and Assessment. 16, 79-80.

Pengilly, J. W., \& Dowd, E. T. (2000). Hardiness and social support as moderators of stress. Journal of Clinical Psychological, 56 (6), 813-820

Pérez-Garín, D., Molero, F., \& Bos, A. E. (2017). The effect of personal and group discrimination on thesubjective well-being of people with mental illness: The role of 
internalized stigma and collective action intention. Psychology, Health \& Medicine, 22(4), 406-414.

Peterson, C., Park, N., Hall, N., \& Seligman, M. E. (2009). Zest and work. Journal of Organizational Behavior, 30(2), 161-172.

Podsakoff, P. M., MacKenzie, S. B., Lee, J. Y., \& Podsakoff, N. P. (2003). Common method biases in behavioral research: A critical review of the literature and recommended remedies. Journal of Applied Psychology, 88(5), 879-903.

Preacher, K. J., \& Hayes, A. F. (2008). Asymptotic and resampling strategies for assessing and comparing indirect effects in multiple mediator models. Behavior Research Methods, 40, 879-891.

Quinn, R. W., Spreitzer, G. M., \& Lam, C. F. (2012). Building a sustainable model of human energy in organizations: Exploring the critical role of resources. The Academy of Management Annals, 6(1), 337-396.

Rautenbach, C., \& Rothmann, S. (2017). Antecedents of flourishing at work in a fast-moving consumer goods company. Journal of Psychology in Africa, 27(3), 227-234.

Rebele, R. W. (2015). Being "otherish": Resolving the false choice between personal and prosocial goals. In R. J. Burke, K. M. Page, \& C. L. Cooper (Eds.), Flourishing in life, work and careers: Individual wellbeing and career experiences (pp. 26-44). Northampton, MA: Edward Elgar.

Pérez-Garín, D., Molero, F., \& Bos., A. E. R. (2017) The effect of personal and group discrimination on the subjective well-being of people with mental illness: the role of internalized stigma and collective action intention, Psychology, Health \& Medicine, 22(4), 406-414, DOI: 10.1080/13548506.2016.1164322

Rice, L. R. (1992). Stress and Health. 2nd ed. (pp 3-4, 6, 12-25). USA: Wadsworth

Riketta, M. (2008). The causal relation between job attitudes and performance: A metaanalysis of panel studies. Journal of Applied Psychology, 93(2), 472-481.

Robert. K., Marie. M., \& Mark M. (2009). HSE Management Standards and stress-related work outcomes. Occupational Medicine, 59, 574-579.

Robertson, I. T., Birch, A. J., \& Cooper, C. L. (2012). Job and work attitudes, engagement and employee performance: Where does psychological well-being fit in? Leadership \& Organization Development Journal, 33(3), 224-232.

Russo, M., Shteigman, A., \& Carmeli, A. (2016). Workplace and family support and work-life balance: Implications for individual psychological availability and energy at work. The Journal of Positive Psychology, 11(2), 173-188.

Schimmack, U., Oishi, S., Radhakrishnan, P., Dzokoto, V., \& Ahadi, S. (2002). Culture, personality, and subjective well-being: Integrating process models of life satisfaction. Journal of Personality \& Social Psychology, 82(4), 582-593.

Seok, C. B., Hashmi, S. I., Chiew, T. C. (2012). The effect of emotional intelligence and job stress on mental health problems: a study among nurses. Southeast Asia Psychological Journal, 1, 56-67.

Sharon E. F. (2011). Wellness and physical therapy. Jones and Bartlett. (pp. 3) United States of America: Publishers LLC

Shirom, A. (2003). Feeling vigorous at work? The construct of vigor and the study of positive affect in organizations. In P. L. Perrewe, \& D. C. Ganster (Eds.), Emotional and physiological processes and positive intervention strategies (pp. 135-164). Greenwich, CN: Emerald Group Publishing Limited. 
Sobel, M. E. (1982). Asymptotic confidence intervals for indirect effects in structural equation models. Sociological Methodology, 13, 290-312.

Soderstrom, M., Dolbier, C., Leiferman, J., \& Steinhardt, M. (2000). The Relationship of Hardiness, Coping Strategies, and Perceived Stress to Symptoms of Illness. Journal of Behavioral Medicine, 23 (3), 311-328.

Sonnentag, S., Kuttler, I., \& Fritz, C. (2010). Job stressors, emotional exhaustion, and need for recovery: A multi-source study on the benefits of psychological detachment. Journal of Vocational Behavior,76(3), 355-365. 24 T. H. BUTT ET AL.

Spreitzer, G. M., Lam, C. F., \& Quinn, R. W. (2012). Human energy in organizations: Implications for POS from six interdisciplinary streams. In the Oxford handbook of positive organizational scholarship (pp. 155-167). New York, NY: Oxford University Press.

Steel, P., Taras, V., Uggerslev, K., \& Bosco, F. (2018). The happy culture: A theoretical, metaanalytic, and empirical review of the relationship between culture and wealth and subjective well-being. Personality and Social Psychology Review, 22(2), 128-169.

Steger, M. F., Kashdan, T. B., \& Oishi, S. (2008). Being good by doing good: Daily eudaimonic activity and well-being. Journal of Research in Personality, 42(1), 22-42.

Taylor, S. E., Kemeny, M. E., Reed, G. M., Bower, J. E., \& Gruenewald, T. L. (2000). Psychological resources, positive illusions, and health. American Psychologist, 55(1), 99-109.

Upadyaya, K., Vartiainen, M., \& Salmela-Aro, K. (2016). From job demands and resources to work engagement, burnout, life satisfaction, depressive symptoms, and occupational health. Burnout Research, 3(4), 101-108.

Varga, S., Piko, B. F., \& Fitzpatrick, K. M. (2014). Socioeconomic inequalities in mental wellbeing among Hungarian adolescents: a cross-sectional study. International Journal for Equity in Health, 13:100. doi:10.1186/s12939-014-0100-8

Veld, M., \& Alfes, K. (2017). HRM, climate and employee well-being: Comparing an optimistic and critical perspective. The International Journal of Human Resource Management, 28(16), 1-20.

Zhai, Q., Willis, M., O'Shea, B., Zhai, Y., \& Yang, Y. (2013). Big five personality traits, job satisfaction, and subjective well-being in China. International Journal of Psychology, 48(6), 1099-1108.

Zhu, Y., \& Akhtar, S. (2014). How transformational leadership influences follower helping behavior: The role of trust and prosocial motivation. Journal of Organizational Behavior, 35(3), 373-392. 